\title{
Seemingly 'impossible' art forms: Strijdom van der Merwe's land art in the context of the South African art market
}

\begin{tabular}{|c|}
\hline $\begin{array}{l}\text { Author: } \\
\text { Jean le Clus-Theron }{ }^{1}\end{array}$ \\
\hline $\begin{array}{l}\text { Affiliation: } \\
{ }^{1} \text { School of Communication } \\
\text { Studies, North-West } \\
\text { University, South Africa }\end{array}$ \\
\hline $\begin{array}{l}\text { Correspondence: } \\
\text { Jean le Clus-Theron }\end{array}$ \\
\hline $\begin{array}{l}\text { Email: } \\
\text { jean.leclus@nwu.ac.za }\end{array}$ \\
\hline $\begin{array}{l}\text { Postal address: } \\
\text { PO Box 19400, Noordbrug, } \\
\text { Potchefstroom 2522, } \\
\text { South Africa }\end{array}$ \\
\hline $\begin{array}{l}\text { Dates: } \\
\text { Received: } 31 \text { Aug. } 2011 \\
\text { Accepted: } 14 \text { May } 2012 \\
\text { Published: } 13 \text { Nov. } 2012\end{array}$ \\
\hline $\begin{array}{l}\text { How to cite this article: } \\
\text { Le-Clus-Theron, J., 2012, } \\
\text { 'Seemingly “impossible" } \\
\text { art forms: Strijdom van der } \\
\text { Merwe's land art in the } \\
\text { context of the South African } \\
\text { art market', Literator 33(1), } \\
\text { Art. \#26, } 10 \text { pages. http:// } \\
\text { dx.doi.org/10.4102/lit. } \\
\text { v33i1.26 }\end{array}$ \\
\hline $\begin{array}{l}\text { Note: } \\
\text { This article was written } \\
\text { as part of, and functions } \\
\text { within the scope of a } \\
\text { larger research project } \\
\text { entitled Transgressions and } \\
\text { boundaries of the page: A } \\
\text { transdisciplinary exploration } \\
\text { of a practice-based research } \\
\text { project by means of the } \\
\text { artist's book conducted by } \\
\text { the subject groups Graphic } \\
\text { Design, Creative Writing } \\
\text { and Art History at the } \\
\text { Potchefstroom Campus of } \\
\text { the North-West University, } \\
\text { South Africa. }\end{array}$ \\
\hline $\begin{array}{l}\text { Project web page: } \\
\text { www.bookboek.co.za }\end{array}$ \\
\hline $\begin{array}{l}\text { C 2012. The Authors. } \\
\text { Licensee: AOSIS } \\
\text { OpenJournals. This work } \\
\text { is licensed under the } \\
\text { Creative Commons } \\
\text { Attribution License. }\end{array}$ \\
\hline
\end{tabular}

This article explored the work of Strijdom van der Merwe, the concept of land art and the notion of the artist's book in the context of the historical and contemporary art market. The premise of the article is the view that if something can be called art, it can also be sold, even if it is an art form that seems 'impossible' to sell, such as land art. This article considers the position of Van der Merwe, the pre-eminent South African land artist, in the somewhat unlikely context, of the South African art market. Van der Merwe is a successful full-time land artist, which is a rare phenomenon in the South African art scene. Indeed in the 1960s, land art was deemed impossible to sell anywhere, and this article explored the extent to which this is still the case today. The research method of the article comprised semi-structured interviews and a literature review. It was argued, in view of Van der Merwe's work, that whilst it may be true that if something can be called art, it can be sold, then the proviso 'somehow' must be added when referring to seemingly 'impossible art'.

Skynbaar 'onmoontlike' kunsvorme: Strijdom van der Merwe se aardkuns in die konteks van die Suid-Afrikaanse kunsmark. Hierdie artikel bied 'n ondersoek na die werk van Strijdom van der Merwe, die gedagte van aardkuns en die kunstenaarsboek in die konteks van die historiese en eietydse kunsmark. Die stelling dat 'indien iets kuns genoem kan word, kan dit ook verkoop word' word gebruik as vertrekpunt - ook in die geval van kunsvorme wat skynbaar 'onmoontlik' is om te verkoop, soos aardkuns. Hierdie artikel besin oor die werk van Strijdom van der Merwe, die bekendste Suid Afrikaanse aardkunstenaar, binne die ietwat ongewone konteks (vir aardkuns) van die Suid-Afrikaanse kunsmark. Hy is 'n suksesvolle voltydse aardkunstenaar; nogal 'n uitsonderlike verskynsel binne die Suid-Afrikaanse kunsomgewing. Aardkuns is allerweë in die 1960s beskou as ' $n$ 'onmoontlike' kunsvorm om te verkoop, en hierdie artikel ondersoek die geldigheid van hierdie stelling vir vandag. Die navorsingsmetode van die artikel is semi-gestruktureerde onderhoude en 'n literatuurstudie. My argument is, met verwysing na Van der Merwe se werk, dat die stelling 'indien iets kuns genoem kan word, dit verkoopbaar is' waar mag wees, maar met die moontlike voorbehoud van 'verkoopbaar - op die een of ander manier'.

\section{Introduction}

Journeys like these are also about the discovering of one self, how you will react to the landscape and the most exciting is how the creative process will unfold as you enter the natural unknown landscape of the island. As I spend most of my time 'outwards' it is very much an 'inward' journey. (Van der Merwe 2009) In this article the work of South Africa's most well-known land artist, Strijdom van der Merwe (b. 1961), and his seemingly 'impossible' to sell art form (land art) are explored with reference to historical and contemporary realties of the art market context (see Art Source South Africa 2010; Ngwenya 2010). Van der Merwe's contribution to the creative research project entitled Transgressions and boundaries of the page, was to combine land art - his primary art form - with conventions from the artist's book Sculpting the Land (2009). It can be argued that the artist's book is a medium that renders Van der Merwe's 'impossible to sell' art form more sellable in the broader art market. Nonetheless, this argument is put forward whilst also taking cognisance of David Paton's (2008) sentiment that the artist's book in itself is still an underappreciated art form in South Africa. In this article, the artist's book will thus be examined alongside land art as a seemingly 'impossible' art form.

The premise of this article is that anything that can be called art is sellable and thus collectible. This is true even of conceptual art forms deemed 'impossible' with reference to the art market context in the 1960s by Messer ${ }^{1}$ (1969:31). For the purposes of this article, land art and the artist's book are likewise positioned as 'impossible'.

1.Thomas M. Messer (b. 1920) served as Director of the Solomon R. Guggenheim museum from 1961 until 1988 (Guggenheim 2011). 
The aim of this article is to inform, and to explore how these two 'impossible' art forms feature in the South African art market. A further aim is to propose that these so-called 'impossible' art forms are in fact sellable and collectible within the 'intermediary machinery', as defined by Messer (1969:31), such as dealers, critics and museums.

The research questions that arise are the following: how can 'impossible' art, land art and the artist's book be defined in view of the current literature? What is the relevance and significance of researching the art of Strijdom van der Merwe? How does seemingly 'impossible' art enter the art market? In what sense is land art a form of 'impossible art'? How has land art evolved from the 1960s until now? And, finally, how can Strijdom van der Merwe's land art and artist's book be positioned in terms of the art market?

With reference to these research questions, the structure of the article is as follows:

- firstly, salient terms are defined

- secondly, the relevance and significance of Strijdom van der Merwe's art is briefly discussed

- thirdly, the art market and the notion of 'impossible' art are explored with reference to the spheres of art history and the art market

- fourthly, a consideration of the way in which land art relates to 'impossible $\mathrm{art}^{\prime}$ and its place within the art market

- finally, I consider the place of Strijdom van der Merwe, his land art and artist's book in the context of the art market.

The salient terms used in this article are discussed in the following section. These are 'impossible' art, land art, and the artist's book.

\section{Clarification of terms: 'impossible art', land art and the artist's book}

\section{'Impossible art'}

Impossible modes of expression [art] are unsuited to the workings of established systems and quietly insist that the system will change to accommodate them or else do without them ... it implicitly denies the channels between artist and viewer, as well as the entire intermediary machinery consisting of dealers, critics and museums. (Messer 1969)

Jacobs' (1970) response to this statement is as follows:

[Messer] sums up the aims and positions of 'impossible' art, but fails to take into account the first two laws of the art game: (1) if it can be called art it somehow can be merchandised; (2) if it is merchandised someone will undoubtedly buy it. (p. 63)

The post-minimal artist Barry Le Va (b. 1941) concurs with Jacobs when he proposes: 'Anything can be bought. Anything can be sold' (quoted in Hapgood 1990:119).

This article supports Le Va and Jacobs' view of the art market as comprised of things that can be merchandised and, therefore, sold through certain channels such as art dealers, art galleries and auction houses. However, exceptions to the rule are the seemingly 'impossible' art forms, such as Van der Merwe's land art as well as the artist's book. The section in this article dealing with 'The place of land art within the art market' presents a reflection on how Van der Merwe uses the artist's book in order to overcome some of the marketing (im) possibilities of land art.

\section{Land art}

Land art, also known as earth art, is a conceptual art movement that emerged during the mid-sixties and seventies, for the most part in the United States of America and Great Britain (Ginsburgh \& Penders 1997; Tate 2012). Artists initially attempted to transcend the restrictions of the gallery environment by moving away from the 'white cube' set-up. They started using the land as their 'canvas' and environmental elements as their 'art brushes' (Ginsburgh \& Penders 1997). Land art is usually created on site using natural materials such as soil, rock, logs, branches, leaves, and water. In some instances artificial materials such as concrete, metal, and mineral pigments have also been chosen. This approach required a redefinition of art forms such as sculpture, because sculptures made in the context of land art are not placed in the landscape; rather, the landscape is the means of their creation. Land art works frequently exist in the open, sometimes far from the built environment. Furthermore, works are often left to transform and erode under natural conditions.

\section{Artist's book}

The second art form of relevance is the artist's book. According to Rossman ${ }^{2}$ ([2003] 2012) this is a genre that is notoriously difficult to define. Indeed, by 2003, she stated, 'the debate over the "true" definition has lasted for almost 25 years.' Drucker (2004:13) concurs that the term 'artist's book' is highly elusive in spite the fairly large number of artists who refer to their art as 'artist's books'. Drucker (2004:14) defines the artist's book as an art form that draws upon a wide spectrum of artistic activities, and yet duplicates none of them. She further regards artist's books as a unique genre - ultimately a genre that is as much about itself, its own forms and traditions, as any other art form or activity. However, it is also a genre that is not as strongly bound by constraints of medium or form as those more familiar genres of painting and sculpture, which also cover a remarkable range of activity.

Rabe $^{3}$ (2011:7) thinks that in order to understand what the artist's book is, one has at times to rely on the power of suggestion. Artists' books are not books, she writes, rather they are works of art that commonly follow either the form or function of what we traditionally think of as a book. Sometimes neither form nor function is present, yet the work still 'feels' like a book. In this sense, the artist's book might look like a book, but not be one, or it might not look like a book but would, in fact, be an artist's book.

\footnotetext{
2.Jae Rossman is assistant director of special collections at Yale University. The article was written in 2003 and was initially posted on the Yale library website but the library does not host this version of the webpage any longer. Rossman sent the library does not host this version of the webpage any longer. Rossman sent the
article to me via email on 28 March 2012. I refer to the date of the emailed article.

3.Jo-Marie Rabe is a cultural historian and the owner of the Gallery Red, black and white in Stellenbosch. She also is a columnist for South African Art Times and Personal Finance (Rabe 2011; Red black and white 2011; Stephan Welz \& Co. 2008).
} 
Roela Hattingh's book As die Gode by ons kom eet [When the Gods come to dine], which formed part of the Transgressions and boundaries of the page exhibition, can be used as an example of an artist's book that is a book, but does not look like a book. Hattingh's 'artist's book' consists of a table that has been set for 12 guests using 26 hand-made ceramic plates inscribed with text. Each plate represents a page from a book. In order to read the story, visitors have to move from one chair to the next, assuming the role of that particular guest for a moment - 'There's a story, but no book', reflects Rabe (2011:7).

Another example is Stephan Erasmus's Axis Mundi: Tree of Sorrow/Tree of Joy (Figure 1). This artist's book consists of two trees made up out of cut up re-written Afrikaans love poems and placed inside a box that looks like a hard-cover book when closed. It does look like a book, but one cannot read it like a book, yet it consists of elements that were readable poems before Erasmus intervened. In this scenario, there is a story, that of the joys and sorrows of love, and there is the essence of a book (cover and pages), yet there is no physical, traditional book.

\section{Strijdom van der Merwe: A brief introduction to the artist and his work}

Van der Merwe started working as a graphic designer in 1984, creating land art in his spare time during this phase of his career. Twelve years later, in 1996, he became a full-time land artist. Commissions made it viable for him to no longer have a 'day job' (Van der Merwe 2011).
Van der Merwe mainly works on a commission basis, constantly creating art and experimenting with projects. Rabe (pers. comm., 05 July 2011), a friend and patron of Van der Merwe, reports that he rarely turns down an artistic opportunity. According to Marley ${ }^{4}$ (2012), Van der Merwe did not hesitate to be part of the Transgressions and boundaries of the page project, and is committed to participating in the North-West University's next project, Reflective conversations: Typography, topography, typology, which was launched in March 2012.

Van der Merwe is a prolific artist. His work has been progressively and consistently featured and presented in national and international magazines since 1995. Popular South African magazines in which his art has been featured include Visi, Style, House and Leisure, Sarie, Taste, Insig, Rooi Rose, Garden E Home and De Kat. He has documented his land art projects in two books published by Protea Book House, Sculpting the Land (2009) and Sculpting the Earth (2012), (Van der Merwe 2011).

Although Van der Merwe has never been represented by a primary dealer, he has received many grants, awards and residencies, media coverage, international exposure, and solo shows in public spaces. One of the most prestigious of these was for the Sculpture Park, Arte Sella, in Borgo

4.Ian Marley is one of the project coordinators of the interdisciplinary creative and research project, 'Transgressions and boundaries of the page' and the newly launched 'Reflective conversations: Typography, topography, typology' (Marley pers. comm., 24 February 2012).

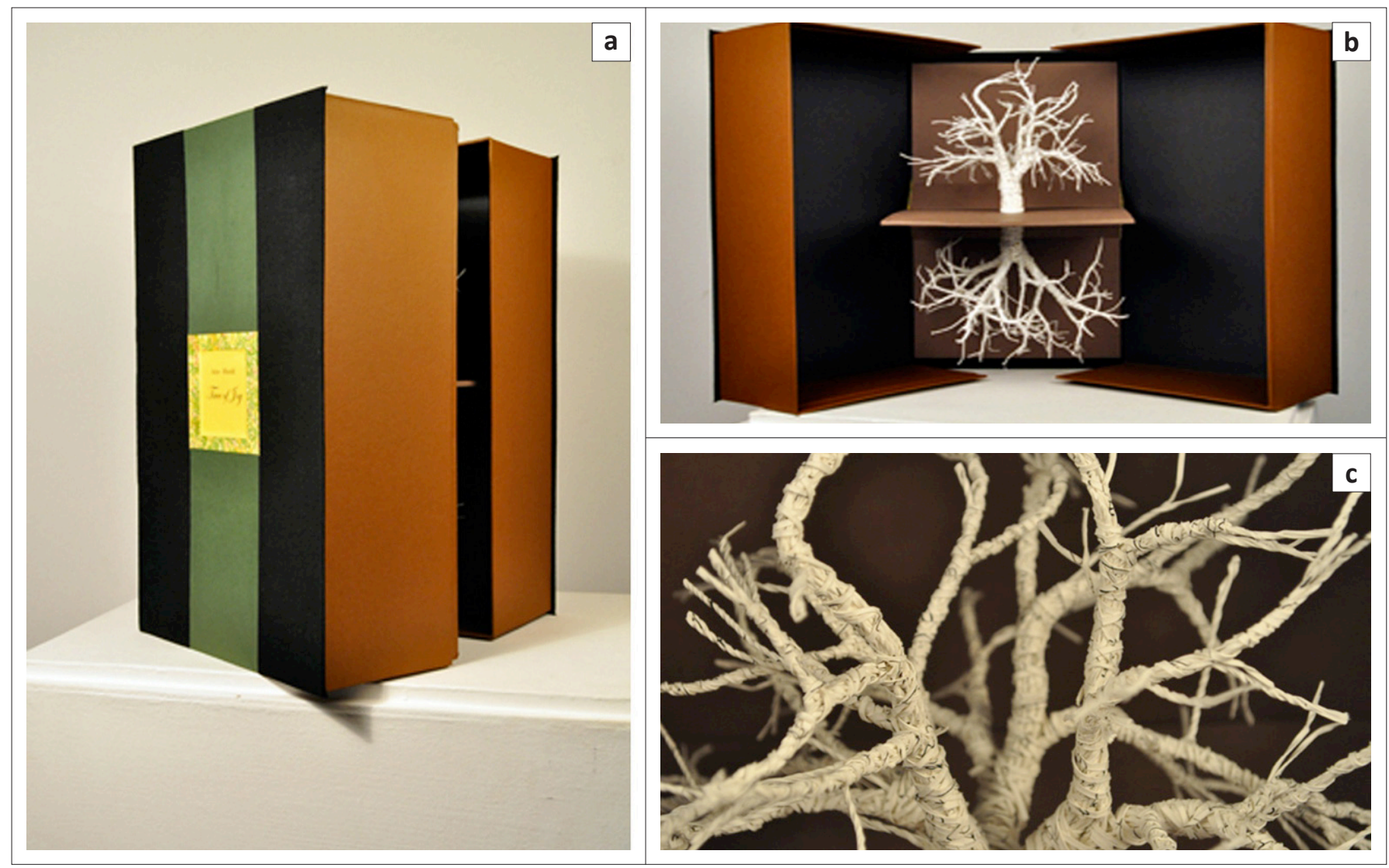

Source: Greyling, F., Marley, I.R. \& Combrink, L. (eds.), 2011, Catalogue of Transgressions and boundaries of the page, North-West University, Potchefstroom Permission to reproduce these images was obtained from the North-West University, Potchefstroom Campus, South Africa.

FIGURE 1: Stephan Erasmus's Axis Mundi: Tree of Sorrow/Tree of Joy. 
Valsugano, Italy (Van der Merwe pers. comm., 05 July 2011; Van der Merwe 2011). Van der Merwe's latest achievement is winning the sculpture and installation category of the It's LIQUID international contest in 2012 for his installation Reaching for the sky (2011) (It's liquid 2012).

\section{The art market}

According to Rabe (pers. comm., 05 July 2011) it is important to distinguish between primary and secondary art markets. The website Wordpress (2010) describes the primary art market as the gallery market, which is activated when an artwork emerges onto the market for the first time. The primary market is also where the prices of artworks are set. The secondary market, on the other hand, is entered once the artwork has been purchased on the primary market and the purchaser, whether a collector or a dealer, decides to resell it. The secondary market includes the auction market.

\section{'Impossible' art within art historical and art market contexts}

Lipman (1970:76) shows in her historical contextualisation (in an article entitled 'Money for money's sake') how artists became fascinated with the US currency as subject matter during the late 19th century. The most radical interpretation of money (or aversion to money) by artists occurred in the context of 'conceptual' art (the 'new art') of the late sixties. Conceptual art was also termed 'impossible' art, because, as Lipman (1970:76) states: 'it is virtually impossible to collect, display, critically evaluate or even accept as art within any previous established framework.' An example of a conceptual artwork that might elucidate the radicalism of the concept is Les Levine's Profit System One (1969), where the artwork comprised a number of things: Firstly, documentation showing the publicity release describing Levine's investment in 500 shares of Cassette Cartridge Corporation stock. Furthermore, the confirmation slip for the securities transaction was mounted on a large sheet of paper which was signed by the artist and then photographed for reproduction. This piece, however, is only a by-product of the transaction; the press release states (Lipman 1970:77): 'The profit or loss of the transaction will become the work of art.' The Whitney Museum of American Art ${ }^{5}$ owns the framed documentation, although, according to Lipman (1970:77), the concept, the actual profit to the artist, and the collector's item documentation of the transaction are all facets of the artwork.

A perceptive entrepreneur who saw the commercial possibilities of 'impossible' art is John Gibson. Rafael Ferrer (b. 1933), initially a conventional sculptor, best describes the bread-and-butter facet of Gibson's entrepreneurial venture as follows:

Ferrer matter-of-factly announced to art columnist Grace Glueck of the New York Times that if the fifteen large melting blocks of

5.The Whitney Museum of American Art presents a full range of 20th century and contemporary American art with a special focus on works by living artists. This museum is dedicated to collecting, preserving, interpreting, and exhibiting American museum is dedicated to collecting, preserving, interpreting, and exhibiting American
art, and its collection is arguably the finest holding of 20th century American art in art, and its collection is arg
the world (Whitney 2011). ice he had installed for the Whitney Museum's Anti-Illusions show were too insubstantial for acquisition by collectors, there was always the iceman's bill - 'a kind of drawing'. (see Lipman 1970:82)

According to Jacobs (1970:63), Gibson was quite literally the iceman amongst the 1970s art dealers and was perceived to typify the dealer of the seventies. Strictly speaking, Gibson did not deal in art at all, but in what he conceived to be the new aesthetics, and the role he chose for himself was the intermediary between artist and sponsor, 'although he pays the rent by selling icemen's bills (or the equivalent thereof) to a surprisingly avid group of collectors' (Jacobs 1970:64).

Just as Gibson's iceman's bill can theoretically become a collector's piece (of an artwork that was once in existence), so a piece of rag from Christo (b. 1935) and Jeanne Claude's (1935-2009) famous wrapped buildings ${ }^{6}$ can become a collector's piece.

Van der Merwe's oeuvre generates memorabilia that can function as collector's pieces and as links to the notion of 'impossible' art that does sell. An example of this would be the haiku poetry flags that were for sale after his land artwork was dismantled at the Klein Karoo National Arts Festival (the KKNK held in Oudtshoorn) in 2008 (Van der Merwe 2011) (Figure 2). Therefore, even though the original artwork as a whole cannot be sold as a 'time capsule', it is still possible to sell memorabilia or documentation of the land art by means of photography and video, as was the case during the Aardklop Arts festival held in 2009. Here Van der Merwe sold the haiku flags for R313 each and the framed photographic prints for R5000 each (Naurattel 2009). The matter of documenting and selling land art is discussed further later on in the article, under the heading The history of land art and documenting photography.

Christo and Jeanne-Claude have sold glossy art books to generate extra income. For example, in 2010 an extensive collection of the documentation of Christo and JeanneClaude's projects were enclosed in a hardcover, 754 page collector's edition of 1000 copies, in a clamshell box, and

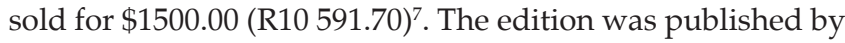
Taschen Books and signed by Christo (Matuse 2011). This is not an example of an artist's book, however: Rossman (2003) explains that there is a crucial difference between presenting an artist's work in a book format, as in the case of Christo and Jeanne-Claude's glossy art book, and an artist making an artist's book, such as Van der Merwe's Sculpting the Land (2009). What makes Van der Merwe's book an artist's book and not another glossy art book is the fact that it was conceptualised and self-published by the artist in a limited edition of four copies. Furthermore, every copy is unique as Van der Merwe produced handwritten text and made drawings separately in each copy after the books had been printed and bound.

6.The Wrapped Reichstag, Berlin (1971-1995) is one of Christo and Jeanne-Claude most famous wrapped buildings. The work of art was entirely financed by the most famous wrapped buildings. The work of art was entirely financed by the artists, like all their previous projects, through the sale of preparatory studies, The artists did not accept sponsorship of any kind (Christo \& Jeanne-Claude 2011).

7.The exchange rate on 30 August 2011 was $\$ 1=$ R7.06 (X-rates 2011). 


\section{Land art as seemingly 'impossible art'}

\section{Land art: History and significance}

Land art can assume different forms, depending on choices made by the artist. These may range from simply walking in nature ${ }^{8}$, documentation of photographs and drawings, to gigantic constructions using trucks and bulldozers in isolated deserts (Ginsburgh \& Penders 1997:219; Tate 2012). An example of a gigantic construction, in Van der Merwe's case, was a commission he undertook for De Beers to turn a desolated mine site into a piece of land art (see Figure 3).

Ginsburgh and Penders (1997:219) write that land art originated, not as a movement with codes and a manifesto, but rather as a group of individuals working and finding their inspiration from similar ideas. Their purposes were diverse and sometimes contradictory, but by rethinking the art object, they tried to find new and alternative ways of using time and space, often engaging remote spaces and producing large-scale projects. One of the reasons for the emergence of land art was that many artists felt 'caged in' by the boundaries of the gallery space, with its rules and regulations - and particularly the modes of selling that accompanied the notion of the gallery - and, thus, they decided to take their art into nature, where there were no boundaries and no conventional rules.

Land art and its significance today was captured in a conversation between Reney Warrington, contributor to Litnet $^{9}$, and Van der Merwe, with reference to Sculpting the Land (2005), land art and the Site_Specific project Van der Merwe was involved in at Plettenberg Bay in May 2011. Warrington asked Van der Merwe: 'Do you create art to give commentary on society? There is a common view that land art is simply decorative', to which Van der Merwe responded:

'Commentary on society' should be defined. In South Africa it will always be seen as political commentary, and if you do not take part in 'struggle' art or have sympathy for it, then your work generally is not seen as giving commentary. My 'voice' thus is not one that speaks of politics, poverty or racial issues.

Yet I see land art, as it is practised today, as significantly commenting on ecological and environmental issues. I do not exhibit a passbook from the seventies, but the subtle handling of nature as an artist's medium and material has a very definite and profound message.

By rearranging the elements of nature, land artists reveal a new world to the public, fostering in them an awareness of the sensitivity and beauty of nature. In itself this approach will lead to a greater awareness of issues of global warming and pollution.

8.For example, Richard Long, in 1967, simply walked up and down until he made a line on the earth (Tate 2012).

9.LitNet is an independent journal on the Internet and a joint venture of Ligitprops $3042 \mathrm{cc}$ and 24.com with Etienne van Heerden as founder-editor (Litnet 2012).
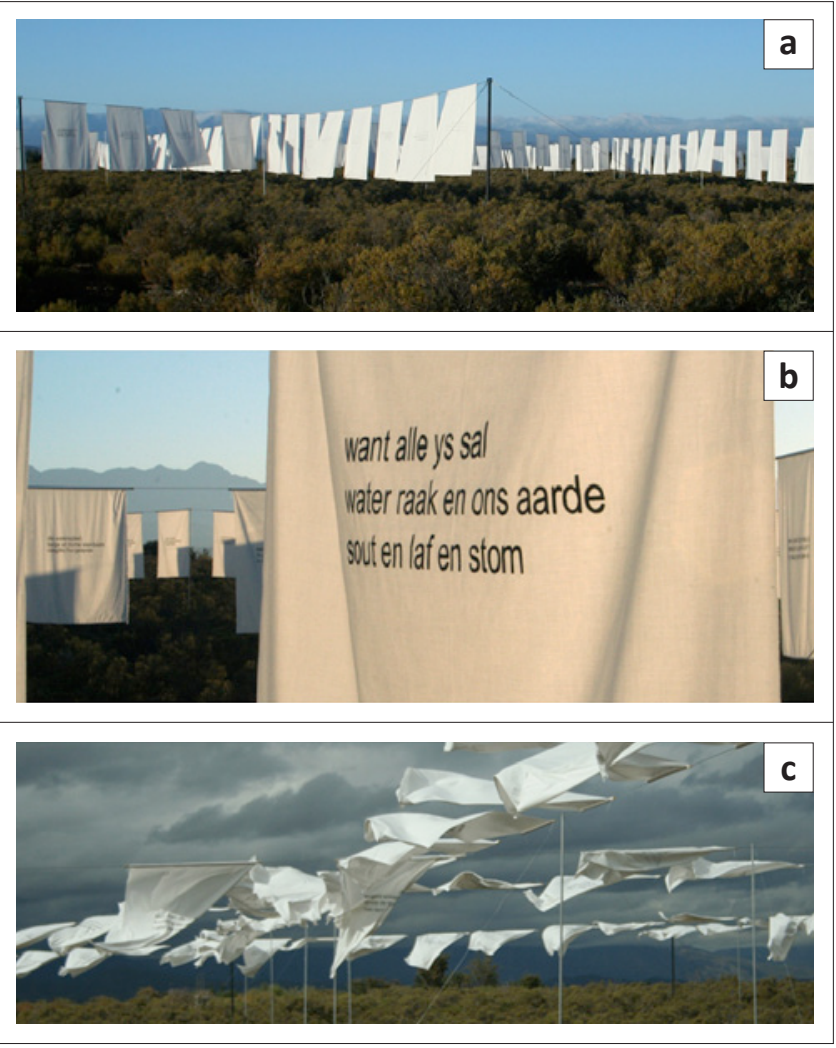

Source: Van der Merwe, S., 2011, Strijdom van der Merwe, viewed 01 July 2011, from http://

Permission to reproduce the image was obtained from the artist.

FIGURE 2: Installation artwork at the Klein Karoo National Arts Festival, Oudtshoorn, South Africa, 2008.
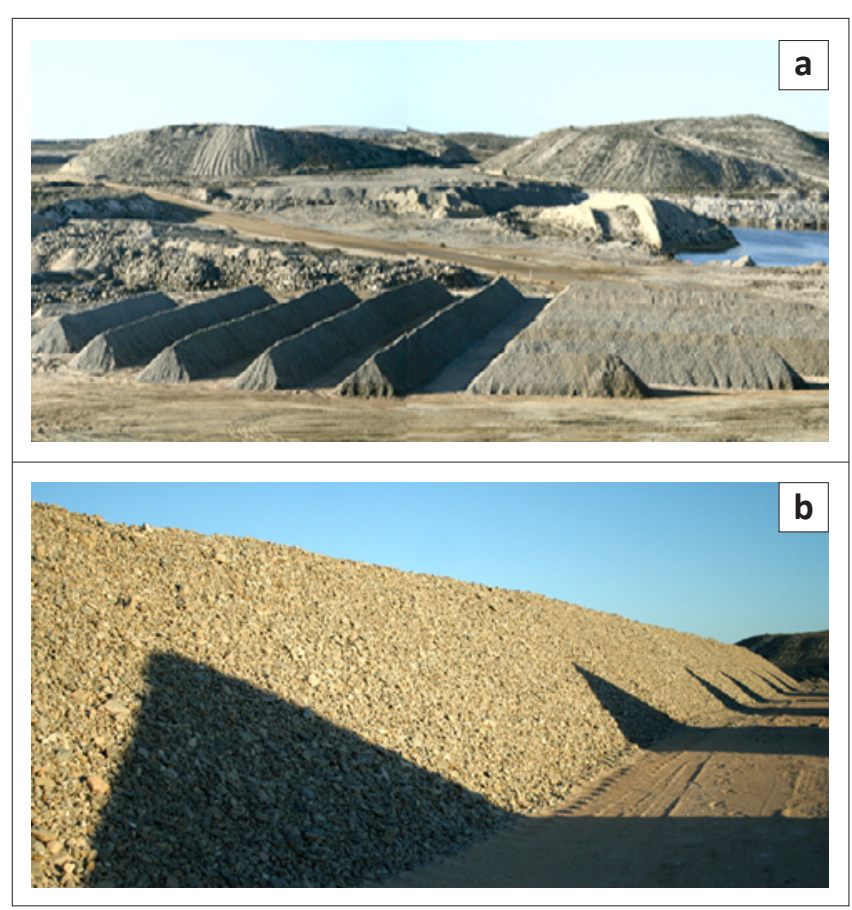

Source: Van der Merwe, S., 2011, Strijdom van der Merwe, viewed 01 July 2011, from http:// www.strijdom.co.za

Permission to reproduce the image was obtained from the artist.

FIGURE 3: am/pm Shadow Lines: Earth Works, Namaqualand Mines, De Beers, South Africa, 2010. 
Therefore I think, for example, that Hannelie Coetzee's rock piles on the beach made people aware again of balance, simplicity, rhythm and the vulnerability of the human being. I heard many stories of people in tears whilst looking at Hannelie's rocks - surely this is a process of public awareness that results in commentary in yourself? To sum up: we give commentary softly and quietly, inwardly, with beauty, 'decoratively', without sacrificing intellectual content. (Van der Merwe \& Warrington 2011:n.p., my transl.)

Observations like this point to the fact that land art complicates conventional notions of sellable art by shifting the focus from the art object to larger concerns such as ecological issues.

When Barbara Freemantle (Van Rensburg 2011), director of the Standard Bank Gallery, was asked where she sees South African art and artists going, she replied:

Art is always a reflection of society and its concerns. We could see more exhibitions dealing with environmental issues. Many artists are grappling with our wasteful destruction of the planet and its resources. South African artists are and should continue to engage with such global issues. That is why I think such artists as Simon Bannister, Marcus Neustetter and Strijdom van der Merwe are so relevant on the art scene today. (p. 55)

A striking example of ecological concerns was seen at an exhibition at the Standard Bank Gallery entitled Water, the [Delicate] Thread of Life that opened on 29 July 2011. Van der Merwe was one of the artists who featured in this group exhibition, together with prominent artists such as William Kentridge, Deborah Bell and Willem Boshoff (Standarbankarts 2011).

\section{The history of land art and documenting photography}

It has been noted above that most practitioners of land art reject the art museum and the gallery as a setting of artistic dissemination. They, therefore, tend to create work beyond the reach of the commercial art market. To prove that the land artworks undoubtedly exist, the artist has to document his or her work by means of video and photographs. This notion of proving means that the documentation of the artwork has become vitally important, because without such documentation, only a very small and select group of observers would be able to appreciate land artworks, and few may be persuaded that the work was indeed produced. Such forms of documentation often become highly sought after collector's items in themselves, although documentation of this nature was not initially intended to function as actual works of art (Ginsburgh \& Penders 1997:220; The Independent 2007; Van der Merwe pers. comm., 05 July 2011).

In this manner, framed documentation by sage 'impresarios' such as John Gibson ended up in the gallery (Jacobs 1970: 62-63) - and were purchased. Documentation of land art led the way for this art form to be sold, ironically, within the gallery environment.

Melvyn Minnaar ${ }^{10}$ (2005:8-9) describes the relationship between land art and documentation photography by

10. Melvyn Minnaar is a freelance journalist who often writes for Art South Africa and South African Art Times (Art South Africa 2009; Art Times 2009). suggesting that even though the documentation of land art may be done with great skill and aesthetic expertise, it is not the artwork itself; it is only produced to 'verify' the creative process. Therefore, the photograph serves as proof that the land art did exist in a particular space and time. Photographic documentation obligates the viewer to reconstruct, to imagine the circumstances in which the land artist intervened in nature.

Van der Merwe defines his approach to land art as a marriage between the two art forms of land art and photography (and video). Clearly, one cannot exist without the other in a gallery situation. The emphasis, however, remains on the land art itself - something that Van der Merwe's approach to photographing his work shows. Although he takes his own photographs, he is not overly concerned with the mechanics of the camera. He believes that the fact that the photograph has aesthetic value can be ascribed to the artistic composition of the land artwork, which means that he simply frames this composition through his lens (Van der Merwe pers. comm., 05 July 2011). As a consequence, the photograph - the sellable item - is actually only a by-product of the process.

\section{Land art as 'impossible' art form}

Certain types of land art cannot 'continue to exist' without the aid of photographs and videos. As a result these art forms function outside the boundaries of the so-called established art system, especially insofar as art dealers, critics and museums are concerned. This notion resonates with Messer's (1969:31) statement cited in the beginning of this article: that 'impossible' art is an art form that denies the intermediary machinations of dealers, galleries and the like. Jacobs (1970) elaborates:

One of the most visible characteristics of the art of the sixties has been an emphatic proclivity towards gigantism that has led a number of painters and sculptors not only to the outer limits of physical feasibility, but in the heady, limitless realms of 'impossible' art. (p. 62)

There may have been no intention to sell land art when it emerged in the mid-sixties, but this does not mean that there was, conversely, any particular desire in all land artists to isolate the works from the market (Ginsburgh \& Penders 1997:221). Whilst Keith Sonnier ${ }^{11}$ recalls that he and his contemporaries took a distinct anti-market stance, many land artists later stated that there was such an unenthusiastic market demand that the question of land art as commodity was not really an issue (Hapgood 1990). The recollections of these artists are, in a sense, reminiscent of Van der Merwe's philosophy for producing art. Whilst some artists create work in order to sell, he has never conceptualised the act of creating an artwork in terms of its selling value, and he believes sincerely this is how it is (or at least should be) with all 'true' artists' work (Van der Merwe pers. comm., 05 July 2011). He imagines that some are born artists who have no choice but to create, whether the work is selling or not selling, commissioned or not commissioned, and he places himself in this category. The conceptual artist (and the land

11.Keith Sonnier (b. 1941) is a minimalist, performance, video and light artist. Sonnier was one of the first artists to use light in sculpture in the sixties, and has been one of the most successful with this technique. He is associated with the process art movement (Blagg 2008). 
artist, by extension) therefore often does exactly what he or she wants to do, whether it is possible for a museum or collector to house, buy or display the final result or not (see also Jacobs 1970:55). This is the type of artist Van der Merwe believes himself to be:

I create art because, firstly it is an amazing experience for me, and it is wonderful for me to see the results, I receive $100 \%$ pure happiness from creating art, and if something comes of it and someone buys it or is interested in buying it, then wonderful. (Van der Merwe pers. comm., 05 July 2011)

\section{The place of land art within the art market}

Commissions are, of course, one possible way of selling land art in its essence. Owners of private or public property may commission artists to create land art on a specific piece of land (site-specific work). In some cases the patrons may allow the public to view these spaces. When the piece of land art is completed, the artist has the option to sell the documentation of the artwork, yet the actual piece of land art belongs to the patron, whether the work lasts for a day or a decade.

Because only a small number of people may have the opportunity to see land art (often because of its customary far-off locations), projects such as site-specific shows are one of the closest approximations of land art to a gallery without gallery walls. The term site-specific refers to land art 'shows' that are produced and displayed in specific areas for the public to view for the duration of its existence. This type of show has emerged across the United States of America and Europe since the 1970s. In South Africa, site-specific shows have appeared notably at art festivals such as the Aardklop Arts Festival and the Klein Karoo National Arts Festival. As noted above, a site-specific international land art festival was held in Plettenberg Bay during May 2011, entitled Site Specific. Van der Merwe was involved both as an artist and organiser of the event. Twenty participating artists, local and international, were asked to create a piece of land art that would last for at least three weeks.

According to Van der Merwe, a 65-page full-colour catalogue entitled Site_Specific, International Land Art Event 2011 was produced in 2011 and introduced to the public in 2012. The catalogue documents and 'exhibits' the entire Site_Specific event. Artists who feature include well-known names such as Gordon Froud, Angus Taylor and Marco Cianfanelli. The book sells together with limited-edition prints (Froud 2011; Site_Specific 2011). Therefore, both the prints and the book situate Site_Specific in the primary art market scene.

Another way in which artists may be part of the art market and earn money with a site-specific show is through sponsors. Ideally, according to Van der Merwe (2011), artists can be paid for participating in a site-specific show. This is not, however, always the case - there was not enough money to pay the artists for Site_Specific in South Africa, but the artists who participated in the show did so out of love for the art form.

According to Ginsburgh and Penders (1997:221), the history of land art and the art market crossed paths when land art entered salerooms around 1969 in Europe and America. The number of sales remained small: only 43 pieces were sold between 1972 and 1977. Ginsburgh and Penders (1997:221) point out that only a few years later, works by land artists were shown and discussed internationally, both in exhibitions and magazines. In this manner, also, 'impossible' art was sold on the secondary market.

\section{Strijdom van der Merwe, his land art and artist's book within the art market}

In terms of documentation, Van der Merwe has created a unique space for his work in the art market by means of memorabilia, photographs, video, permanent structures, art books and the artist's book he produced.

Interestingly, the extensive (and often beautiful) documentation of Van der Merwe's work has given rise to commissions for permanent structures. In an interview on 05 July 2011, Van der Merwe explained that the permanent structures he had produced are deeply connected with and related to his land art. A few of his permanent structures include the red tree sculpture in Bloemfontein produced for the University of the Free State (Figure 3), a construction in front of Rabe's Red black and white gallery in Stellenbosch, and the work produced for Casparus, a restaurant in Stellenbosch (Van der Merwe pers. comm., 05 July 2011; Van der Merwe 2011). These, of course, are commissions that yield an income as this work is sold to the patron and is, thus, an instance of land art giving rise to sellable art.

The documentation of Van der Merwe's work has also given rise to the production of his artist's book. As mentioned before, the artist's book tends to receive little public appreciation in the South African context. However, according to David Paton ${ }^{12}$ (2008), there is a traceable history of book art production at South African universities, and there are a number of artists who are committed to the book arts in South Africa. A number of individuals also avidly collect artist's books. Jack Ginsberg, internationally renowned Johannesburg-based artist's book collector, is a prime example of such a collector. Artists, scholars and bibliophiles from all over the world visit Ginsberg's collection, which is unique on the African continent. This collection constitutes the heart of the website South African artist's books (Paton 2012).

The artist's book is another means through which the work of Van der Merwe has become marketable. The artist created his artist's book Sculpting the Land (2009) after a four-week artist's residency at Rantum on the island Sylt in Germany. The Stiftung kunst:raum sylt quelle, sponsored by the bottling concern Sylt-Quelle, invites artists from all disciplines and countries for periods of residency on the island. Here Van der Merwe created, and thereafter documented, his land art

12.David Paton is the creator of the research website www.theartistsbook.org.za which aims to share information, development and ideas around the South African artist's book (Paton 2008). 
by means of photographs and video. For these works, Van der Merwe made markings on the sand, arranged rocks and sticks in harmonious forms and structures in the surrounding environment, in a one kilometre radius around the main building of the Foundation kunst:raum sylt quelle. In one video, he filmed himself pouring water (Sylt-Quelle bottled water) over a bridge, with water running beneath him. The video is entitled 'Drawing with Water: Water over Bridge', 2 min 08s (2009) (Figure 5) (Jozi-artlab 2012; Kunst:raum sylt quelle 2012; Van der Merwe 2011). It is important to note in this regard that an artist's residency was not directly connected to the art market, but when an artist sells the documentation of
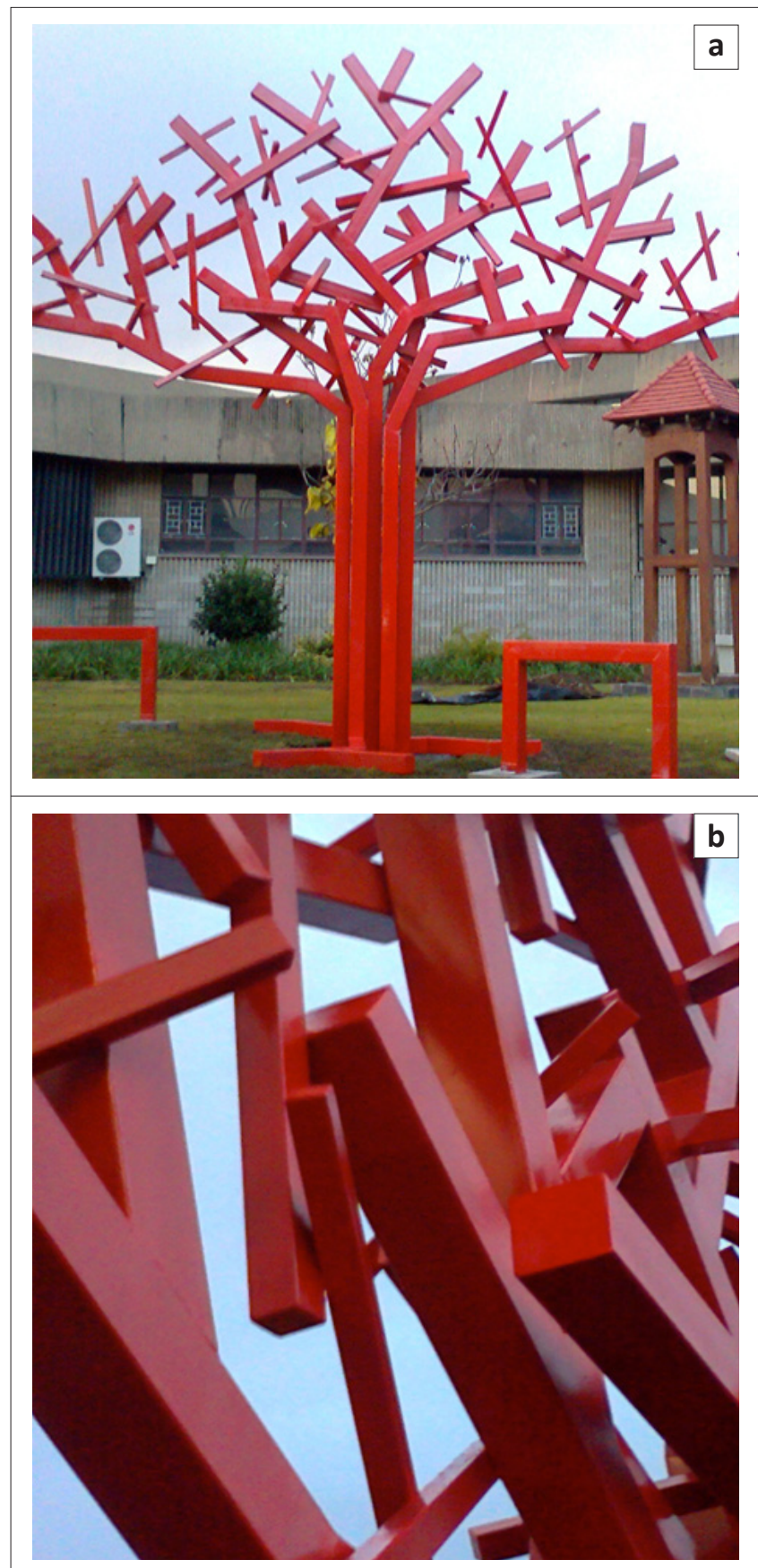

Source: Van der Merwe, S., 2011, Tree of Knowledge, viewed 01 July 2011, from http://www strijdom.co.za

Permission to reproduce the image was obtained from the artist.

FIGURE 4: Tree of Knowledge situated in front of the Winkie Direko Building at the University of the Free State in Bloemfontein, South Africa. the work from such an art residency, the artwork enters the realm of the art market.

Upon his return to South Africa, Van der Merwe selected the best photographs from his residency on Sylt and transformed them into a 48 page artist's book. It is a hardcover book with dimensions of $440 \mathrm{~mm} \times 300 \mathrm{~mm} \times 200 \mathrm{~mm}$, in landscape format and printed by a small company in Stellenbosch named 'Picture Works'. As an introduction to the artist's book, the South African poet and writer Charl-Pierre Naudé wrote a section about Van der Merwe's land art and Naudé's own residency on the island Sylt. The pages of the book consist of photographs of the artworks. Between some of the pages the reader or viewer of Van der Merwe's book will find handwritten bits of narrative, by the artist, about his experiences on Sylt. Some of these bits of text are written on translucent paper, and some on the printed pages next to the photographs documenting the land art. The handwritten text throughout the book describes Van der Merwe's journey: on the first page a diary entry appears of his train ride towards his destination (Sylt), and on the last page one finds a diary entry on journey back to civilisation. Only four copies of the book were produced, and each is individually written and drawn in by the artist - each copy is therefore unique.

Van der Merwe's artist's book Sculpting the Land (2009) sells for R20 000, whereas his first commercial book, also titled Sculpting the Land (2005) and published by Protea Book House, sells for R350. His latest commercial book, entitled Sculpting the Earth (2011), also published by Protea Book House, additionally sells for R350. Images from the Sylt project are displayed in Sculpting the Earth (Van der Merwe 2005; Van der Merwe 2009; Van der Merwe pers. comm., 05 July 2011; Van der Merwe 2011). It is noteworthy at this point to reiterate the difference between an art book and an artist's book. According to Rossman (2003), the art book is published through a publishing house and it is mass produced, whereas an artist's book is conceived entirely by the artist, self-published, unique in one way or another and is produced once-off or in a limited edition.

The large price gap between the artist's book and the art book is ascribed to the fact that an artist's book is one of a kind, and is therefore a work of art, whereas commercial books are mass-produced. The individuality of the artist's book gives the book the stature that allows it to be sold at a higher price (Rabe 2011).

The fact that Van der Merwe's artist's book was selfpublished in a limited edition and is distributed directly by the artist, also confirms this book's status as an artist's book, and not simply a book that documents his land art.

It is interesting to note a similarity between the artist's book and land art in terms of the emphasis on process and the desire to subvert the establishment. Gordon Froud (2011) describes the process of creating an artist's book as hypnotising and obsessive. Van der Merwe similary describes 'creating' land art as meditative (Froud 2011, Van der Merwe 2011). For Van 

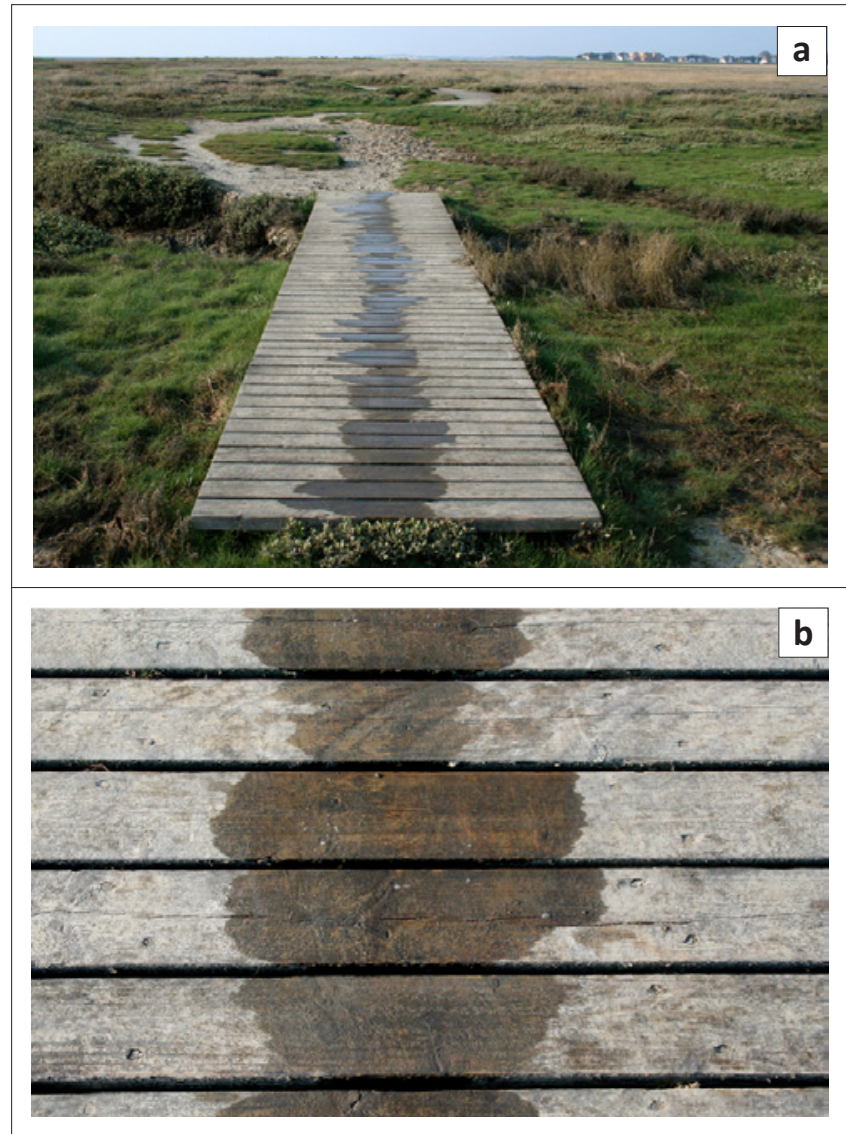

Source: Van der Merwe, S., 2011, Drawing with Water: Water over Bridge, viewed 01 July 2011, from http://www.strijdom.co.za

Permission to reproduce the image was obtained from the artist.

FIGURE 5: Video still from Drawing with Water: Water over Bridge at the island Sylt, April 2009.

der Merwe, the process is the most important aspect of art making (Van der Merwe \& Warrington 2011). He describes the importance of the creative process: 'The excitement of seeing an artwork happening in an environment and the influence the landscape has on the artist stays, for me, one of the best creative improvisation processes' (Van der Merwe pers. comm., 05 July 2011).

Accompanying Sculpting the Land (2009) is a DVD copy of Van der Merwe's video Drawing with water: Water over Bridge, 2 min 08s (see Figure 5) captured during his residency on Sylt. Video is another medium that adds to the significance of his artist's book and is a means of involving the viewer closely with the 'making' of the art, and the importance of the process involved in the creation of land art.

\section{Summary and conclusion}

In this article the stature of the artist Strijdom van der Merwe as land artist was discussed along with his use of the artist's book and other marketable manifestations of this so-called 'impossible' to sell art form. Both land art and the artist's book were considered with reference to the art market, and it has been found that both are represented in a very small percentage of the art world's art market.

Within the historical art market context, work by Strijdom van der Merwe has not yet been sold in the secondary market, but his work has indeed been present on the primary art market through the sales of his land art documentation. Land artworks as such, on the other hand, have since 1969 indeed (although rarely) been presented for sale at auctions (the secondary market) in Europe and America (Ginsburgh \& Penders 1997). With reference to the artist's book Rossman (2003) noted that the artist's book is bought and sold as an investment and as a highly prestigious object of a private collectable nature.

Land art enters the art market through the mediation of documentation. Of course, the documentation is not the 'real' artwork, but nonetheless it has been shown that the one art form (land art) cannot sell on the art market without the other art form (documentation), one of which, in the case of Van der Merwe, is the artist's book. Of course, land art can exist regardless of whether it is documented or not. It is simply not feasibly marketable without documentation, although perhaps not completely unmarketable. Marketability could increase if the work is shown in a public space or if an admission fee is charged.

This article set out to situate 'impossible' art forms, namely land art and the artist's book, together with Strijdom van der Merwe's approach to these in the context of the art market. It was also deemed important to place Van der Merwe's work and stature in a more academic context than is usually the case.

With reference to the premise of this article (anything that is called art is sellable and thus collectible), this article explored land art and the artist's book in order to establish that these art forms are indeed sold within the South African art market, although not abundantly so. According to Rabe (pers. comm., 05 July 2011), the fashion of the time dictates what sells. It therefore follows that as soon as land art and artist's books become more 'fashionable', an increase in sales of these art forms will most likely occur in the art market.

A number of similarities emerged between land art and the artist's book in the course of the article. Both land art and the artist's book are conceptual art trends that originated in the 1960s. Both these tendencies avoided commercialism and rather explored ways of transcending conventional boundaries. It seems fortuitous that Van der Merwe created a version of multidisciplinary art making by marrying his land art with the artist's book (an art form that is characteristically multidisciplinary). These two art forms complement each other, as both are highly process-driven and yield unique pieces of art, which can be attractive for collectors to collect and own.

\section{Suggestions for further research}

Relational aesthetics is a term brought to my attention by a guest referee of Literator who suggested that I include the theory of relational aesthetics in my article as part of my theoretical framework. Although I find the concept of relational aesthetics engaging, I felt that it warrants a separate 
investigation. Relational art, or aesthetics, is an art form that is linked to the idea of 'impossible' art forms. According to Bourriaurd (1998), relational art exploits the act of human interaction as an art form. Therefore, it would be interesting and challenging to explore how the act of interaction, as an art form, can sell on the art market. However, it is my contention that documentation of relational art (using video and photographs) can be used to sell 'the event' that took place. Therefore I believe that relational aesthetics can add to the discourse of 'impossible' to sell art forms, further exploring the premise of this article, namely if something can be called art, it can be sold.

\section{Acknowledgements}

I would like to thank Strijdom van der Merwe and Jo-Marie Rabe, for taking time out of their busy schedules to meet with me at the inception of this article in July 2011 and for their interest in this project.

\section{Competing interests}

The author declares that she has no financial or personal relationships which may have inappropriately influenced her in writing this article.

\section{References}

Art source South Africa, 2010, Sculpting the Land at Arts on Main, viewed 21 July 2011, from http://www.artlink.co.za/news_article.htm?contentID=23856

Art South Africa, 2009, Melvyn Minnaar, viewed 30 August 2011, from http://www. artsouthafrica.com/?article $=631$

Arttimes, 2009, Saat Columnist: Melvyn Minnaar - The artful viewer, viewed 30 August 2011, from http://www.arttimes.co.za/news_read.php?news_id $=620$

Blagg, M., 2008, Keith Sonnier, viewed 17 August 2012, from http://www. interviewmagazine.com/art/keith-sonnier/

Bourriaurd, N., 1998, Relational aesthetics, Les Presses du Réel, Dijon.

Christo and Jeanne-Claude, 2011, Wrapped Reichstag, viewed 29 August 2011 from http://www.christojeanneclaude.net/major_reichstag.shtml

Circagallery, 2012, Strijdom van der Merwe, viewed 28 February 2012, from http:// www.circagallery.co.za/?m=10\&s=12

Drucker, J., 2004, The century of artists' books, Granary Books, New York.

Froud, G., 2011, 'Altered books - Verbal and PowerPoint presentation during Transgressions and boundaries of the page colloquium', Potchefstroom, 13 July 2011. (Camera recording and PowerPoint presentation in possession of the author.)

Ginsburgh, V. \& Penders, A.F., 1997, 'Land art and art markets', Journal of Cultural Economics 21, 219-228.

Greyling, F., Marley, I.R. \& Combrink, L. (eds.), 2011, 'Transgressions and boundaries of the page: Catalogue, Faculty of Arts, North-West University, Potchefstroom, Potchefstroom.

Hapgood, S., 1990, 'Remaking art history', Art in America (July), 115-122.
It's liquid, 2012, International contest, viewed 13 August 2012, from http://www. itsliquid.com/contest/2012/winners.html

Jacobs, J., 1970, 'The Iceman cometh; symptoms of the seventies', Art in America (Jan-Feb), 62-67.

Jozi-Artlab, 2012, South African artist on Sylt, viewed 12 August 2012, from http:// www.jozi-artlab.co.za/en/klip_town_art_project/south_african_artists-sylt strijdom.php

Kunst:raum sylt quelle, 2012, Artists, concepts, communication, viewed 12 April 2012 , from http://www.kunstraum-syltquelle.de/en/stipendien/index.php

Lipman, J., 1970, 'Money for money's sake', Art in America (Jan-Feb), 76-83.

Litnet, 2012, About us, viewed 09 April 2012, from http://www.litnet.co.za/Category/ als-oor-litnet/wie-is-ons

Matuse, 2011, Christo \& Jeanne-Claude, viewed 29 April 2011, from http://matuse. com/shop/books/147/

Messer, T., 1969, 'Impossible art: Why it is', Art in America (May-Jun), 30-31.

Minnaar, M., 2005, 'Significantly a southern shaman', in S. van der Merwe (ed.), Sculpting the Land, pp. 6-9, Protea Boekehuis, Pretoria.

Naurattel, C., 2009, 'Visual art sales: Aardklop 2009', documentation sent via e-mail to author on 28 February 2012.

Ngwenya, J.B., 2010, Strijdom van der Merwe recreates the land with his art, viewed 30 June 2012, from http://www.senseonline.co.za/index.php/Archives/Strijdomvan-der-Merwe-Recreates-the-Land-with-his-Art.html

Paton, D., 2008, What will be the canon for the artist's book in the 21st century: Case study interview with David Paton, viewed 12 July 2011, from http://www. bookarts.uwe.ac.uk/canon.htm

Paton, D., 2012, South African artists' books, viewed 27 February 2012, from http:// www.theartistsbook.org.za/view.asp?pg=about

Red Black and White, 2011, Red black and white, viewed 22 July 2011, from http:// www.redblackandwhite.co.za/home.htm

Rabe, J., 2011, 'When a book is not a book', in F. Greyling, I.R. Marley \& L. Combrink (eds.), Transgressions and boundaries of the page: Catalogue, pp. 6-8, Faculty of Arts, North-West University Potchefstroom.

Rossman, J.J., 2003, email, 01 April 2012.

Site_Specific, 2011, Press, viewed 25 August 2011, from http://sitespecific.org. za/?page id $=32$

Standardbankarts, 2011, 'Water, the delicate thread of life: Various artists', viewed 16 August 2011, from http://www.standardbankarts.com/Gallery/CurrentExhibition.aspx

Stephan Welz \& Co., 2008, 'Arts as an Investment' features increasingly in media coverage, viewed 24 June 2011, from http://www.swelco.co.za/Index.cfm? fuseaction=news.start\&ID=4226591

Tate, 2012, 'Land art', viewed 27 February 2012, from http://www.tate.org.uk/ collections/glossary/definition.jsp?entryld=151

The Independent, 2007, 'Land art: Natural expressions', viewed 22 July 2011, from http:// www.independent.co.uk/travel/americas/land-art-natural-expressions-440797.html

Van der Merwe, S., 2005, Sculpting the Land, Protea Boekehuis, Pretoria.

Van der Merwe, S., 2009, Sculpting the Land - Artist's book.

Van der Merwe, S., 2011, Strijdom van der Merwe, viewed 01 July 2011, from http:// www.strijdom.co.za

Van der Merwe, S. \& Warrington, R., 2011, 'Strijdom van der Merwe gesels oor sitespecific, landkuns en sy nuwe boek', viewed 25 June 2011, from http://www. litnet.co.za/Article/strijdom-van-der-merwe-gesels-oor-site-specific-landkuns

Van Rensburg, W., 2011, 'Barbara Freemantle: Director of Standard Bank Gallery', South African Art Times: Business Art (May), 54-55.

Whitney, 2011, About the Whitney, viewed 19 August 2011, from http://whitney.org/ About

Wordpress, 2010, Art collecting and investment: Definition of primary and secondary art market, viewed 27 February 2012, from http://theartistsloft.wordpress. com/2010/08/30/definition-of-primary-and-secondary-art-market

X-Rates, 2011, 'Currency calculator', viewed 10 July 2011, from http://www.x-rates. com/calculator.html 